\title{
PERTANGGUNGJAWABAN PIDANA KORPORASI TERHADAP HAK PENYANDANG DISABILITAS DI BIDANG KETENAGAKERJAAN DALAM UNDANG- UNDANG NOMOR 8 TAHUN 2016 TENTANG PENYANDANG DISABILITAS
}

\author{
CRIMINAL RESPONSIBILITIES OF THE CORPORATE \\ TOWARD THE RIGHTS OF PEOPLE WITH DISABILITIES \\ IN THE FIELD OF EMPLOYMENT ACCORDING TO \\ LAW NUMBER 8 OF 2016 CONCERNING PEOPLE WITH \\ DISABILITIES
}

\author{
Regy Trihardianto \\ Fakultas Hukum Universitas Airlangga \\ Email : regytrihardianto@yahoo.com
}

Naskah diterima : 10/02/2018; direvisi : 20/03/2018; disetujui : 27/04/2018

\begin{abstract}
Corporate is one of criminal law subject according to law number 8 of 2016 concerning people with disabilities. Corporate in this law refer to either legally establish or selfestablish corporate. This law arranged two kinds of corporate responsibilities namely administrative sanction and cumulative criminal sanction. According to this law penalties are sentenced in form of imprisonment and fines. Responsibilities model applied by this law is "act by corporate, responsible by its caretaker" due to cumulative criminal sanction regulated under this law.
\end{abstract}

Keywords: people with disabilities, corporate criminal responsibilities, corporate.

\begin{abstract}
Abstrak
Korporasi menjadi salah satu subjek hukum pidana dalam Undang-undang Nomor 8 Tahun 2016 tentang Penyandang Disabilitas. Korporasi yang dimaksud dalam Undang-undang ini adalah korporasi yang berbadan hukum maupun yang tidak berbadan hukum. Pertanggungjawaban Korporasi di dalam Undang-undang ini ada 2 (dua) macam, yang pertama sanksi administratif dan juga sanksi pidana kumulatif. Sanksi Pidana yang di jatuhkan dalam Undang-undang ini adalah berupa pidana penjara dan pidana denda. Model pertanggungjawaban pidana korporasi yang digunakan undang-undang adalah berupa "Korporasi berbuat, pengurus yang bertanggungjawab", dikarenakan sanksi pidana kumulatif yang ada pada undangundang tersebut.
\end{abstract}

Kata Kunci : Penyandang Disabilitas, Pertanggungjawaban Pidana, Korporasi 


\section{PENDAHULUAN}

Lahirnya Konvensi tentang HakHak Penyandang Disabilitas atau Convention on the Rights of Persons with Disabilities (CRPD) merupakan wujud perubahan paradigma gerakan disabilitas pada level masyarakat internasional. Gerakan yang awalnya melihat para penyandang disabilitas sebagai "obyek" amal, pengobatan dan perlindungan sosial (charity atau social based) telah berubah menjadi gerakan berbasis hak asasi manusia (human rights based). Menariknya Indonesia menjadi Negara ke-9 yang menandatangani Konvensi tentang Hak-Hak Penyandang Disabilitas (Convention on the Rights of Persons with Disabilities/CRPD) dan meratifikasinya secara resmi pada 10 November 2011. Langkah maju dari Pemerintah dan DPR tentu perlu diapresiasi namun persoalan tidak berhenti hanya dengan melakukan ratifikasi terhadap Konvensi tentang Hak-Hak Penyandang Disabilitas (Convention on the Rights of Persons with Disabilities/CRPD), ada banyak langkah yang harus dibenahi untuk memperkuat perlindungan terhadap para penyandang disabilitas khususnya dalam sistem hukum pidana nasional, yang salah satu bentuknya adalah dengan disahkannya Undang-Undang Nomor 8 Tahun 2016 tentang Penyandang Disabilitas.

Dalam Pasal 9 Undang-Undang Nomor 19 Tahun 2011 Tentang Pengesahan Konvensi Hak-Hak Penyandang Disabilitas juga mengatur bahwa penyandang disabilitas agar dapat mampu hidup secara mandiri dan berpartisipasi penuh dalam segala aspek kehidupan, Negara wajib mengambil langkah yang tepat untuk menjamin akses bagi penyandang disabilitas atas dasar kesamaan dengan warga lainnya, terhadap lingkungan fisik, transportasi, informasi dan komunikasi termasuk juga sistem serta teknologi informasi dan komunikasi serta akses terhadap fasilitas dan jasa pelayanan untuk publik dan juga hak untuk mendapatkan pekerjaan dalam artian seorang penyandang disabilitas tidak akan ditolak dalam melamar suatu pekerjaan karena keadaannya yang kurang.

Penghormatan, Pelindungan, dan Pemenuhan hak Penyandang Disabilitas merupakan kewajiban negara. Hal ini juga ditegaskan dalam Undang-Undang Nomor 39 Tahun 1999 tentang Hak Asasi Manusia, sehingga masyarakat mempunyai tanggung jawab untuk menghormati hak Penyandang Disabilitas. Penyandang Disabilitas selama ini mengalami banyak Diskriminasi yang berakibat belum terpenuhinya pelaksanaan hak Penyandang Disabilitas. ${ }^{1}$

Berdasarkan data terakhir dari WHO (2011) menyebutkan bahwa jumlah penyandang disabilitas di dunia pada tahun 2010 adalah sebanyak 15,6 persen dari total populasi dunia atau lebih dari 1 (satu) milyar. Jika penduduk Indonesia saat ini sebanyak 247 juta jiwa, itu berarti jumlah penyandang disabilitas berdasarkan estimasi WHO tersebut di atas sekitar 37.091.000 jiwa. ${ }^{2}$

Sementara itu, data dari PUSDATIN Kemensos RI, mencantumkan bahwa jumlah penyandang disabilitas yang menjadi sasaran kebijakan dan program pemerintah di Indonesia adalah 1.163.508 jiwa. Data tersebut digunakan dalam Renstra Kemensos RI dan RPJNM 2010$2015 .^{3}$

Keterbatasan fisik dan/atau mental yang dimiliki oleh seorang penyandang disabilitas banyak dimanfaatkan oleh orang-orang yang memiliki niat buruk untuk melakukan sesuatu yang melanggar hukum terhadap seorang penyandang disabilitas. Banyak kasus kekerasan

\footnotetext{
${ }^{1}$ Penjelasan Umum Undang-Undang Nomor 8 Tahun 2016 tentang Penyandang Disabilitas

${ }^{2}$ Naskah Akademik RUU Penyandang Disabilitas, h. 4

${ }^{3}$ Naskah Akademik RUU Penyandang Disabilitas, h.
} 
seksual yang dialami oleh perempuan dengan disabilitas mencapai $93 \% \quad$ (57 dari 61 kasus) $)^{4}$. Penyandang disabilitas sering dianggap sebagai kelompok rentan oleh masyarakat, hal ini dikarenakan posisi para penyandang disabilitas yang direntankan oleh teks dan sistem aparatur negara.

Kewajiban Negara untuk melindungi (the obligation to protect) adalah kewajiban untuk tidak hanya terfokus pada upaya perlindungan dari pelanggaran yang dilakukan negara, namun juga terhadap pelanggaran atau tindakan yang dilakukan oleh entitas atau pihak lain (non-negara) yang akan mengganggu perlindungan hak penyandang disabilitas, Termasuk dalam hal ini adalah perlindungan yang dilakukan oleh negara untuk menghindarkan penyandang disabilitas dari ancaman kesia-siaan, penelantaran atau eksploitasi dan lain-lain. Sedangkan kewajiban untuk memenuhi (the obligation to fulfill) adalah kewajiban negara untuk mengambil langkah-langkah legislatif, administratif, yudisial dan praktis, yang perlu dilakukan untuk memenuhi hak penyandang disabilitas yang dijamin oleh konstitusi maupun peraturan perundang-undangan, dalam hal ini negara wajib menyediakan berbagai fasilitas fisik dan non fisik khususnya jaminan pemeliharaan dan kesejahteraan secara permanen kepada penyandang disabilitas dari kalangan kategori berat. Secara teoritik bahwa konsep perlindungan hukum bertujuan untuk mewujudkan masyarakat madani (civil society) dalam rangka mewujudkan masyarakat adil dan makmur yang merata, baik materiil maupun spiritual dalam era demokrasi ekonomi berdasarkan Pancasila dan Undan-Undang Dasar $1945 .{ }^{5}$

\footnotetext{
https://www.komnasperempuan.go.id/wp-content/uploads/2017/04/CATAHU-2017-Komnas-Perempuan.pdf, diakses pada tanggal 06 September 2017, pukul 16.37 WIB.

${ }^{5}$ Ahmad Zuhairi, Konstruksi Perlindungan Hukum Bagi Pengadu/Pelapor Kerugian Konsumen Dari Tuntutan Pencemaran Nama Baik Oleh Pelaku Usaha/Produsen,
}

Di Indonesia sendiri ada beberapa peraturan perundang-undangan yang ditunjukan sebagai dasar aturan untuk menghormati, melindungi, dan memenuhi hak-hak penyandang disabilitas, yaitu Undang-Undang Nomor 8 Tahun 2016 tentang Penyandang Disabilitas. Undang-undang tersebut adalah undangundang yang menggantikan UndangUndang Nomor 4 Tahun 1997 Tentang Penyandang Cacat, yang mana Undangundang ini dianggap belum berspektif hak asasi manusia, dan lebih bersifat belas kasihan (charity based) dan pemenuhan haknya masih dinilai sebagai masalah sosial yang kebijakan pemenuhan haknya baru bersifat jaminan sosial, rehabilitasi sosial, bantuan sosial dan peningkatan kesejahteraan sosial.

Undang-Undang Nomor 8 Tahun 2016 mencantumkan mengenai hakhak dari para penyandang disabilitas yang harus dilindungi dan dihormati tidak hanya oleh pemerintah, melainkan juga oleh masyarakat pada umumnya dan perusahaan-perusahaan yang ada di Indonesia. Dalam berbagai peraturan perundang-undangan hukum pidana Indonesia dikatakan bahwa pengertian korporasi itu adalah kumpulan terorganisasi dari orang/ dan atau kekayaan baik merupakan badan hukum maupun bukan. ${ }^{6}$ Korporasi tidak lain merupakan suatu badan yang dibentuk sebagai kebutuhan untuk menjalankan suatu kegiatan yang diberi status sebagai subjek hukum, di samping subjek hukum yang alamiah (manusia). Korporasi (badan hukum) ini oleh hukum diakui sebagai pendukung hak dan kewajiban.

Dengan adanya Pasal 144 dan Pasal 145 dalam Undang-Undang Nomor 8 Tahun 2016 tentang Penyandang Disabilitas,

Jurnal Ius Kajian Hukum dan Keadilan, Vol. III, No. 7, Edisi April 2015, hlm. 55

${ }^{6}$ H. Setiyono, Kejahatan Korporasi: Analisis Viktimologis dan Pertanggungjawaban Korporasi dalam Hukum Pidana Indonesia, Bayumedia Publishing, Malang, 2003. hlm. 17. 
maka dapat dikatakan bahwa tindak pidana kepada penyandang disabilitas tidak hanya dapat dilakukan oleh orang perseorangan, akan tetapi dapat dilakukan oleh korporasi.

Berdasarkan uraian di atas, adapun yang menjadi pokok permasalahan yaitu bagaimana bentuk pertanggungjawaban pidana korporasi terhadap hak penyandang disabilitas di bidang ketenagakerjaan dalam Undang-Undang Nomor 8 Tahun 2016 tentang Penyandang Disabilitas tersebut.

\section{PEMBAHASAN}

Bentuk Pertanggungjawaban Pidana Korporasi terhadap Hak Penyandang Disabilitas di Bidang Ketenagakerjaan dalam Undang-Undang Nomor 8 Tahun 2016 tentang Penyandang Disabilitas

Pertanggungjawaban pidana dalam istilah asing disebut juga dengan teorekenbaardheid atau criminal responsibility yang menjurus kepada pemidanaan petindak dengan maksud untuk menentukan apakah seseorang terdakwa atau tersangka dipertanggungjawabkan atas suatu tindakan pidana yang terjadi atau tidak.

Dalam ilmu hukum pidana dikenal suatu asas dalam pertanggungjawaban pidana yaitu asas geen straf zonder schuld; actus non facit reum nisi mens sit rea yang memiliki arti tidak dapat dipidananya seseorang jika tidak memiliki suatu kesalahan ${ }^{7}$. Asas ini memang tidak tertulis dalam hukum positif Indonesia namun asas ini diakui dalam hukum Indonesia sebagai suatu hukum yang tidak tertulis ${ }^{8}$.

Dari adanya hubungan yang mengikat antara suatu perbuatan dengan suatu kesalahan, maka menurut Moeljatno ikatan tersebut dinyatakan sebagai suatu hubungan sifat melawan hukumnya perbuatan (wederrechdelijkheid) dan

\footnotetext{
7 Moeljatno, Asas-Asas Hukum Pidana Cet. VII, Rieneka Cipta, Jakarta, 2009., hlm. 165

${ }^{8}$ Ibid
}

kesalahan (schuld). Dikatakan bahwa "kesalahan tidak dapat dimengerti tanpa adanya suatu sifat melawan hukumnya perbuatan", Namun hal tersebut berlaku sebaliknya dengan "sifat melawan hukum mungkin ada tanpa adanya kesalahan"9. Dari pernyataan tersebut dapat diambil suatu kesimpulan bahwa, "orang tidak mungkin dipertanggungjawabkan (dijatuhi pidana) kalau tidak melakukan perbuatan pidana. Tetapi meskipun melakukan perbuatan pidana, tidak selalu dapat dipidana"10.

Adanya kesalahan merupakan unsur mutlak yang bisa mengakibatkan dimintakannya pertanggungjawaban pidanasipelakudelik. Pertanggungjawaban atas tindak pidana yang dilakukan oleh seseorang itu adalah untuk menentukan kesalahan dari tindak pidana yang ia lakukan. Pertanggungjawaban pidana atau criminal rensposibility artinya seseorang yang telah melakukan suatu tindak pidana belum berarti harus dipidana. Ia harus mempertanggungjawabkan perbuatan yang telah dilakukannya jika ditemukan unsur kesalahan padanya. ${ }^{11}$ Karena suatu tindak pidana itu terdiri atas a criminal act (actus reus) dan a criminal intent (mens rea). ${ }^{12}$ Actus reus atau guilty act dan mens rea atau guilty mind ini mutlak ada untuk pertanggungjawaban pidana. ${ }^{13}$ Pertanggungjawaban pidana hanya dapat terjadi setelah sebelumnya dia melakukan tindak pidana. ${ }^{14}$ Jadi, tindak pidana dipisahkan dari pertanggungjawaban

\footnotetext{
${ }^{9}$ Ibid, h.167

${ }^{10}$ Ibid

${ }^{11}$ Suharto R.M., Hukum Pidana Materiil: Unsur-Unsur Objektif sebagai Dasar Dakwaan, Edisi Kedua, Sinar Grafika, Jakarta, 1996, h. 106

12 Robert W. Emerson sebagaimana dikutip oleh Hasbullah F. Sjawie, Direksi Perseroan Terbatas serta Pertanggungjawaban Pidana Korporasi, PT. Citra Aditya Bakti, Bandung, 2013, h. 252

${ }^{13}$ Paul Dobson sebagaimana dikutip oleh Hasbullah F. Sjawie, Direksi Perseroan Terbatas serta Pertanggungjawaban Pidana Korporasi, PT. Citra Aditya Bakti, Bandung, 2013, h. 252

14 Chairul Huda, Dari Pidana Tanpa Kesalahan Menuju kepada Tiada Pertanggungjawaban Pidana Tanpa Kesalahan, Kencana, Jakarta, 2006, h. 20
} 
pidana atau dipisahkan dari unsur kesalahan. ${ }^{15}$ Pengecualian prinsip actus reus dan mens rea ini ada pada delik yang bersifat strict liability, di mana mens rea tidak perlu dibuktikan. ${ }^{16}$

Pertanggungjawaban pidana ini sendiri sudah muncul sejak zaman Revolusi Prancis, pada masa itu tidak saja manusia yang dapat dipertanggung jawab kan tindak pidana bahkan hewan atau benda mati lainnya pun dapat dipertanggungjawabkan tindak pidana. Seseorang tidak saja mempertanggungjawabkan tindak pidana yang dilakukannya, akan tetapi perbuatan orang lain juga dapat dipertanggungjawabkan karena pada masa itu hukuman tidak hanya terbatas pada pelaku sendiri tetapi juga dijatuhkan pada keluarga atau teman-teman pelaku meskipun mereka tidak melakukan tindak pidana.

Namun setelah Revolusi Prancis pertanggungjawaban pidana didasarkan atas dasar falsafah kebebasan berkehendak yang disebut dengan teori tradisionalisme, kebebasan berkehendak dimaksud bahwa seseorang dapat dimintai pertanggungjawaban pidana atas dasar pengetahuan dan pilihan, menurut teori ini seseorang yang pada usia tertentu dapat membedakan dan memisahkan mana yang dikatakan perbuatan baik dan mana yang tidak baik.

Pertanggungjawaban pidana mengandung asas kesalahan (asas culpabilitas), yang didasarkan pada keseimbangan monodualistik bahwa asas kesalahan yang didasarkan pada nilai keadilan harus disejajarkan berpasangan dengan asas legalitas yang didasarkan pada nilai kepastian. Walaupun Konsep berprinsip bahwa pertanggungjawaban pidana berdasarkan kesalahan, namun dalam beberapa hal tidak menutup kemungkinan adanya

\footnotetext{
${ }^{15}$ Moeljatno, Op.Cit, h. 57

${ }^{16}$ Roger Geary, Understanding Criminal Law, Cavendish Publishing Limited, Oregon, 2002, h. 7
}

pertanggungjawaban pengganti (vicarious liability) dan pertanggungjawaban yang ketat (strict liability). Masalah kesesatan (error) baik kesesatan mengenai keadaannya (error facti) maupun kesesatan mengenai hukumnya sesuai dengan konsep merupakan salah satu alasan pemaaf sehingga pelaku tidak dipidana kecuali kesesatannya itu patut dipersalahkan kepadanya. ${ }^{17}$

Pertanggungjawaban pidana (criminal responsibility) dapat dikatakan sebagai suatu mekanisme untuk menentukan apakah seseorang terdakwa atau tersangka dapat dipertanggungjawabkan atas suatu tindakan pidana yang terjadi atau tidak. Untuk dapat dipidananya si pelaku, disyaratkan bahwa tindak pidana yang dilakukannya itu memenuhi unsur-unsur yang telah ditentukan dalam undangundang.

Berkaitan dengan pertanggungjawaban ini, maka seseorang hanya dapat dibebani tanggung jawab pidana bukan hanya karena dia telah melakukan perbuatan yang dilarang atau melanggar kewajiban yang dipersyaratkan undang-undang, yang harus dapat dibuktikan penuntut umum, tetapi juga bahwa pada saat perbuatan itu dilakukan, pelakunya harus memiliki mens rea. ${ }^{18} \mathrm{Hal}$ ini merupakan salah satu ciri dari hampir semua sistem hukum, di mana tanggung jawab pelaku atas tindak pidana yang telah dilakukannya selalu dikaitkan dengan keadaan-keadaan tertentu dari mentalnya. ${ }^{19}$

A criminal act atau actus reus diartikan sebagai suatu perbuatan yang melanggar ketentuan hukum pidana suatu pelanggaran untuk melakukan sesuatu yang dipersyaratkan oleh hukum. Sedangkan criminal intent atau mens rea

${ }^{17}$ Barda Nawawi Arief, Masalah Penegakan Hukum dan Kebijakan Penanggulangan Kejahatan, PT. Citra Aditya Bakti, Bandung, 2001, hlm. 23.

${ }^{18}$ Hasbullah F. Sjawie, Op.Cit

${ }^{19}$ Roeslan Saleh, Pikiran-Pikiran Tentang Pertanggungjawaban Pidana, Ghalia Indonesia, Jakarta, 1982, h. 20 
diartikan sebagai suatu tindak pidana, yang dilakukan oleh seorang pelaku dengan an evil purpose or with blameworthly or person endangering state of mind. Dengan kata lain mens rea diartikan sebagai unsur mental si pelaku. Jadi, perbuatan itu dipisahkan dari kesalahan dan apabila ada perbuatan dan kesalahan, kepada pelakunya dapat dimintakan criminal liability atau pertanggungjawaban pidananya. Begitu pentingnya elemen kesalahan ini, maka dikatakan actus non facit reum, nisi mens sit rea atau an act does not make a person guilty, unless the mind is guilty. ${ }^{20}$

Asas actus reus dan mens rea itu berarti bahwa suatu perbuatan tidak dapat membuat orang bersalah, kecuali apabila dilakukannya dengan niat jahat. ${ }^{21}$ Ada dua hal yang menjadi pokok penting dari asas actus reus dan mens rea. Pertama, perbuatan lahiriah sebagai penjelmaan dari kehendak, misalnya, perbuatan mengambil pada perkara pencurian. Kedua, kondisi jiwa, apakah perbuatan itu dilakukan dengan maksud jahat atau tidak. 22

Istilah kesalahan (schuld) adalah pengertian hukum yang tidak sama dengan pengertian harfiah, fault. Kesalahan dalam hukum pidana merupakan faktor penentu pertanggungjawaban pidana $^{23}$ atau mengandung beban pertanggungjawaban pidana, yang terdiri atas kesengajaan atau kelalaian. ${ }^{24}$ Seseorang dapat dikatakan bersalah melakukan suatu perbuatan atau telah menimbulkan sesuatu yang dilarang oleh undang-undang apabila perbuatannya yang menimbulkan akibat yang dilarang itu didasarkan pada suatu kesengajaan ataupun pada suatu kealpaan. ${ }^{25}$ Perbuatan

\footnotetext{
${ }^{20}$ Hasbullah F. Sjawie, Op.Cit

${ }^{21}$ Gerson W. Bawengan, Hukum Pidana di dalam Teori dan Praktek, Pradnya Paramita, Jakarta, 1983, h. 51

${ }^{22}$ Ibid

${ }^{23}$ Chairul Huda, Op.Cit., h. 27

${ }^{24}$ Adami Chazawi, Pelajaran Hukum Pidana Bagian 1: Stelsel Pidana, Tindak Pidana, Teori-Teori Pemidanaan dan Batas Berlakunya Hukum Pidana, Raja Grafindo Persada, Jakarta, 2008, h. 91

25 P.A.F Lamintang, Dasar-Dasar Hukum Pidana Indonesia, Sinar Baru, Bandung, 1984, h. 188
}

yang terjadi karena kesengajaan pembuatnya saja yang dijadikan tindak pidana, sedangkan perbuatan yang terjadi karena kealpaan, hanya dijadikan tindak pidana jika perbuatan itu dipandang cukup serius. ${ }^{26}$

Dewasa ini kesalahan tidak lagi dipandang semata dalam pengertian psikologis, yaitu sekedar kesengajaan atau kealpaan, dalam arti ada hubungan batin antara orang yang melakukan perbuatan dan perbuatannya. Akan tetapi telah berkembang di mana yang penting bukannya bagaimana keadaan batin orang yang berbuat, melainkan penilaian orang lain terhadap keadaan batin tadi. ${ }^{27}$

Dalam hukum pidana, masalah kesalahan ini menjadi demikian penting karena dikenal dalam hukum pidana asas legalitas, yaitu tiada hukuman kalau tak ada kesalahan atau nullum delictum nulla poena sige lege poenali. Asas ini secara implisit tercantum dalam Pasal 1 ayat (1) KUHP, yang berbunyi sebagai berikut :

"Tiada suatu perbuatan boleh dihukum, melainkan atas kekuatan ketentuan-ketentuan pidana dalam undang-undang, yang ada terdahulu daripada perbuatan itu"

Asas legalitas; asas nulla poena dipandang sebagai suatu bagian yang sangat penting dari kepastian hukum dan merupakan asas fundamental dalam negara hukum (suatu penghubung antara rule of law dan hukum pidana) yang penyimpangannya hanya dimungkinkan oleh hukum darurat. $^{28}$ Asas ini diperkenalkan pertama kali tahun 1981 oleh Paul Johann Anseln von Feurbach dalam bukunya Lehrbuch des Peinlichen Recht, yang artinya tiada suatu perbuatan dapat dipidana, kecuali atas kekuatan aturan pidana dalam perundang-undangan

\footnotetext{
${ }^{26}$ Chairul Huda, Op.Cit., h. 34

${ }^{27}$ Chairul Huda, Op.Cit., h. 77

28 Oemar Seno Adji, Hukum (Acara) Pidana Dalam Prospeksi, Erlangga, Jakarta, 1984, h. 188
} 
yang telah ada sebelum perbuatan tersebut dilakukan. ${ }^{29}$

Korporasi sebagai subjek hukum pidana memiliki perbedaan dengan orang perseorangan yang diakui juga sebagai subjek hukum pidana. Korporasi merupakan subjek hukum yang tidak mempunyai mens rea atau keinginan untuk melakukan perbuatan jahat. Korporasi seperti yang kita ketahui bersama merupakan kumpulan orang atau merupakan kumpulan kekayaan yang terorganisasi, dari hal tersebut muncul sebuah pertanyaan apakah kumpulan kekayaan memiliki perasaan untuk berbuat atau kumpulan orang memiliki perasaan yang sama untuk bertindak?, maka dari hal itulah korporasi ini dinyatakan tidak memiliki mens rea atau keinginan untuk melakukan perbuatan jahat.

Korporasi berasal dari bahasa latin "corporatio" yang dalam setiap kata yang berakhiran "tio" merupakan bentuk kata benda yang berasal dari kata kerja "corporare" yang berarti memberi badan atau membadankan atau dengan kata lain badan yang dijadikan orang-orang sebagai hasil ciptaan hukum sebagai lawan terhadap badan manusia yang terjadi menurut alam. Badan hukum dalam konteks bahasa dapat diartikan sebagai suatu ciptaan hukum kecuali penciptanya, maka kematiannya pun ditentukan oleh hukum. ${ }^{30}$

Satjipto Rahardjo juga memberikan pengertian korporasi dan dikutip oleh Fahrizal Pranata Bahri "badan hasil ciptaan hukum yang terdiri dari corpus, yaitu yang terstruktur fisiknya dan kedalamannya unsur memasukkan unsur animus yang membuat badan mempunyai kepribadian". ${ }^{31}$

\footnotetext{
${ }^{29}$ Hasbullah F. Sjawie, Op.Cit, h. 258

${ }^{30}$ Soetan K. Malikoel Adil, Pembaharuan Hukum perdata Kita, PT .Pembangunan, Jakarta, 1955, h. 83.

${ }^{31}$ Fahrizal Pranata Bahri, Pertanggungjawaban Korporasi Terhadap Tindak Pidana Pemalsuan Domain Dalam Pengaturan Hukum Pidana Indonesia, (Jurnal Skripsi Universitas Mataram), Mataram, 2013, h. 8.
}

Korporasi yang merupakan suatu ciptaan dari hukum, maka korporasi ini sendiri memiliki ciri-ciri ${ }^{32}$ :

1. Korporasi tidak mempunyai mens rea (keinginan untuk berbuat jahat).

2. Korporasi bukan seorang pribadi meskipun korporasi dapat melakukan berbagaiperbuatanhukumyangbiasanya dilakukan oleh orang pribadi.

3. Korporasi tidak memiliki kesadaran dan tidak memiliki badan aktual.

4. Korporasi tidak dapat dimintai pertanggungjawaban karena tidak ada kejahatan yang dilakukan oleh direksi suatu korporasi, hal tersebut sudah pasti merupakan perbuatan di luar anggaran dasar dari korporasi yang bersangkutan, sehingga dalam halseperti itu maka yang bertanggungjawab adalah direksinya secarapribadiataudireksinya secara bersama-sama dengan direksi yang lain, tetapi bukan korporasi yang bertanggungjawab (doktrin ultra vires). Pertanggungjawaban korporasi pada saat ini sudah murni diakui oleh Indonesia, Peter Gillies mengatakan bahwa korporasi atau perusahaan adalah orang atau manusia di mata hukum, dan karenanya mampu melakukan sesuatu sebagaimana yang dilakukan manusia, diakui oleh hukum sebagai suatu kekayaan, dapat melakukan kontrak sehingga seharusnya harus dapat dipertanggungjawabkan atas tindak pidana yang dilakukannya. ${ }^{33}$

Hukum pidana menemukan beberapa teori yang patut dipergunakan untuk mempidana korporasi atau meminta pertanggungjawaban pidana korporasi atas perbuatan yang dilakukan yaitu :

1. Teori pertanggungjawaban atas dasar kesalahan (Lialbility Based On Fault)

Teori ini pada prinsipnya mengatakan bahwa subjek hukum dapat dimintai pertanggungjawaban pidana

${ }^{32}$ Rufinus Hotmaulana Hutauruk, Penanggulangan Kejahatan Korporasi Melalui Pendekatan Restoratif, Cetakan Pertama, Sinar Grafika, Jakarta Timur, 2013, h. 19 .

${ }^{33}$ Ibid, h. 47. 
Regy Trihardianto| Pertanggungjawaban Pidana Korporasi Terhadap Hak Penyandang Disabilitas di...........

bila terlebih dahulu dapat dibuktikan adanya suatu kesalahan atau yang dikenal dengan istilah mens rea, dengan mengidentifikasi suatu kesalahan yang dilakukan oleh korporasi melalui cara mengaitkan perbuatan mens rea para individu yang mewakili korporasi selaku directing mind atau alter ego ${ }^{34}$.

2. Teori Pertanggungjawaban pidana atas setiap tindakan dari pegawai dan pengurusnya (Vicarius Liabilility)

Menurut Barda Nawawi Arif, vicarius liabilility diartikan sebagai tanggung jawab menurut hukum seorang atas perbuatan salah yang dilakukan oleh orang lain (the lega lresponsibility of one person for the wrongful acts of another) atau secara singkat dapat dikatakan pertanggungjawaban pengganti ${ }^{35}$. Dalam perbuatan hukum yang dilakukan oleh bawahan suatu korporasi, seharusnya dan sepatutnya hal tersebut dapat dibuktikan dalam bentuk tertulis, dikarenakan dalam hal melakukan pembuktian terhadap suatu keterangan maka harus disandingkan dengan bukti tertulis lainnya sebagai bukti penguat.

Teori ini pada dasarnya adalah untuk menjawab pertanyaan, apakah terhadap seseorang itu dapat dipertanggungjawabkan secara pidana atas tindak pidana yang dilakukan oleh oranglain.Pertanyaaninimunculkarena pada dasarnya pertanggungjawaban pidana itu merupakan hal pribadi.

3. TeoriPertanggungjawaban pidana tanpa membuktikan terlebih dahulu adanya kesalahannya (Strict Liability) atau pertanggungjawaban mutlak.

Strict Liabillity atau absoluteliability atau liability without fault atau tanggung jawab mutlak ini dimaknai oleh Black's Law Dictionary sebagai: ${ }^{36}$

\footnotetext{
${ }^{34}$ Ibid, h. 48.

35 Barda Nawawi Arief, Perbandingan Hukum Pidana, Rajawali Perss, Jakarta, 1990, h. 33.

${ }^{36}$ Bryan A. Garner, Op.Cit
}

"Liability that does not depend on actual negligence or intent to harm, but that is based on the breach of an absolute duty to make something safe. Strict liability most often applies either to ultra hazardous activities or in product liability case."

Mengenai pengertian Strict Liability ini, Barda Nawawi Arif mengatakan bahwa seorang sudah dapat dipertanggungjawabkan walaupun pada orangitu tidakadamensreauntuk tindaktindak pidana tertentu ${ }^{37}$. Barda Nawawi Arif menyatakan demikian dengan alasan ${ }^{38}$ :

1) Sangat esensial untuk menjamin dipatuhinya peraturan-peraturan penting tertentu yang diperlukan untuk kesejahteraan masyarakat.

2) Pembuktian adanya mens rea akan menjadi sangat sulit untuk pelanggaran-pelanggaran yang berhubungan dengan kesejahteraan masyarakat itu.

3) Tingginya tingkat "bahaya sosial" yangditimbulkanolehperbuatanyang bersangkutan.

4. Teori Identifikasi

Terhadap doktrin bahwa perseroan terbatas adalah badan hukum yang mandiri, akan menimbulkan permasalahan hukum apabila bertemu dengan bagian dari hukum yang berlaku terhadap orang alamiah, yang membutuhkan penilaian terhadap keadaan mental seseorang, dalam kaitannya dengan pengenaan pertanggungjawaban. Dalam hal demikian, pengadilan telah mengambil jalan menerapkan teori organ, yang menyamakan badan hukum itu selayaknya manusia dan organorgannya, yang salah satu organnya adalah pusat pikiran atau otak.

Menurut teori ini, korporasi dapat melakukan tindak pidana secara langsung melalui orang-orang yang

\footnotetext{
${ }^{37}$ Rufinus Hotmaulana Hutauruk, Op.cit, h. 58. ${ }^{38}$ Ibid.
} 
sangat berhubungan erat dengan korporasi dan dipandang sebagai korporasiitusendiri,sepanjangtindakan yang dilakukan itu terkait dengan korporasi, dilakukan oleh orang yang berkapasitas atau berwenang untuk itu, dan dilakukannya secara intra vires. ${ }^{39}$

Adanya suatu tindak pidana bukan berarti sudah pasti akan ada suatu pertanggungjawaban pidana karena tindak pidana hanya menunjuk pada suatuperbuatanatauakibatyangdilarang dan bagi pelanggarnya diancam dengan suatu pidana. Untuk pelakunya, apakah dijatuhi pidana seperti yang diancam pada pasal yang dilanggar, sangat tergantung dari jawaban apakah dia mempunyai kesalahan atau tidak, sebab pada hukum pidana dikenal dengan asas "tiadapidanatanpakesalahan"(geenstraf zonder schuld; actus non facit reum nisi mens sir rea). Di Indonesia sendiri sudah ada beberapa korporasi mendapatkan hukuman dari pengadilan, seperti kasus PT. Dong Woon Enviromental Indonesia dalam Putusan Mahkamah Agung RI No. 862K/Pid.Sus/2010 dan Kasus PT. Kalista Alam dalam Putusan PengadilanNegeriMaelabohNomor131/ Pid.B/2013/PN.MBO.

Pertanggungjawaban pidana korporasi mengani hak penyandang disabilitas di bidang ketenagakerjaan dalam UU Penyandang Disabilitas ini tidak akan terlepas dari tindakan korporasi yang melanggar aturan-aturan hukumpadaUUPenyandangDisabilitas. Hal itu berarti sebelum korporasi ini dimintakan pertanggungjawaban, haruslah dipahami terlebih dahulu terhadap adanya bentuk perbuatan yang dilakukan oleh korporasi dan alasan korporasidapatdikatakansebagaipelaku tindak pidana, dan nantinya akan timbul suatu pertanyaan apakah perbuatan yang dilakukan itu dapat dimintai pertanggungjawaban.

\footnotetext{
${ }^{39}$ Hasbullah F. Sjawie, Op.Cit, h. 308
}

Korporasi itu sendiri menjadi salah satu subjek hukum pidana dalam UU Penyandang Disabilitas dengan adanya ketentuan Pasal 1 angka 17 mengenai pengertian mengenai "Setiap Orang" yang mana diartikan sebagai orang perseorangan atau korporasi, baik itu korporasiyangberbadanhukummaupun korporasi yang tidak berbadan hukum. Penjelasan mengenai korporasi sebagai subjek juga ada pada Pasal 1 angka 15 mengenai pengertian "Pemberi Kerja", yaitu orang perseorangan, pengusaha, badan hukum, atau badan lainnya yang mempekerjakan tenaga kerja dengan membayar upah atau imbalan dalam bentuk lain.

Namun dalam UU Penyandang Disabilitas ini, terkait dengan apabila tindak pidana tersebut dilakukan oleh korporasi, tidak dicantumkan mengenai siapa yang harus bertanggungjawab nantinya, pertanggungjawaban dalam Ketentuan Pidana UU Penyandang Disabilitas adalah merupakan sanksi pidana dengan sistem kumulatif, dalam artian jika ada beberapa jenis pidana pokok yang diancamkan dalam suatu ketentuan hukum pidana, maka hakim harus menjatuhkan keseluruhannya, yang di mana sanksi dalam kedua pasal tersebut adalah sanksi pidana penjara disertai dengan pidana denda, hal tersebut menjadi suatu masalah, karena korporasi tidak mungkin untuk dipenjara. Mahrus Ali memberikan dua pernyataan, Pertama, pertama bahwa korporasi tidak mungkin untuk melakukan suatu perbuatan maka korporasi dinyatakan berbuat atau tidak berbuat melalui atau diwakili oleh orang perseorangan atau disebut sebagai suatu tindakan fungsional. Kedua, sebagai suatu konsekuensi dari pernyataan yang pertama maka korporasi dapat 
melakukansuatuperbuatanberdasarkan perantara pengurusnya. ${ }^{40}$

Terkait dengan pernyataan di atas, timbul suatu pertanyaan, yaitu jika perbuatan itu dilakukan oleh orang perseorangan, apakah korporasi juga harus bertanggungjawab sebagai pelaku, nyatanya korporasi tidak dapat melakukan perbuatan secara nyata sehingga susah untuk menyatakan korporasi sebagai pelaku, berbeda halnya dengan orang perseorangan yang memang mampu untuk melakukan perbuatansecaranyatadanmudahuntuk dinyatakan sebagai pelaku.

Untuk menjawab pertanyaan tersebut, penulis mengkutip pernyataan yang diberikan oleh W.J.Brown: ${ }^{41}$

"Dapat dikatakan bahwa korporasi adalah sebuah pribadibuatan dengan sebuah kepribadian hukum yang secara penuh berbeda dan terpisah dari manusia-manusia sebagai anggota yang melakukan pengendalian dan menjalankan korporasi melalui basis hukum perusahaan"

Berdasarkan pernyataan di atas dikaitkan dengan pertanyaan tadi, maka dapat ditarik kesimpulan bahwa "senyatanya suatu perbuatan yang dilakukan oleh orang perseorangan dalam lingkup korporasi, merupakan bentuk nyata dari perbuatan korporasi itu sendiri".

Mardjono Reksodiputro berpendapat, sebagaimana yang telah dicantumkan Hasbullah F. Sjawie dalam bukunya ${ }^{42}$, ada tiga sistem di Indonesia berkenaan dengan kedudukan sebagai pembuat dan sifat pertanggungjawaban korporasi, yakni:

1. Pengurus korporasi sebagaipembuat dan penguruslah yang bertanggungjawab.

2. Korporasi sebagai pembuat dan penguruslah yang bertanggungjawab.

${ }^{40}$ Mahrus Ali, Asas-Asas Hukum Pidana Korporasi, Edisi 1, Cet. 1, Rajawali Press, Jakarta, 2013, h. 74-75.

41 W.J.Brown, Practical Company Law, Pan Book Ltd, Cavaye Place, Londong SW 19 9PG First Published, 1984, h. 12. Dikutip dari buku Rufinus Hotmaulana Hutauruk, Op.cit, h. 21.

${ }^{42}$ Hasbullah F. Sjawie, Op.Cit, h. 272
3. Korporasi sebagai pembuat dan juga sebagai yang bertanggungjawab.

Berkaitan dengan Pasal 144 dan Pasal 145 UU Penyandang Disabilitas yang penulis telah cantumkan di atas, setelah membaca pendapat Mardjono mengenai sistem pertanggungjawaban pidana korporasi di Indonesia, tentunya dapat dilihat bahwa UU Penyandang Disabilitas ini menganut sistem "Korporasi sebagai pembuat dan penguruslah yang bertanggungjawab". Hal ini dikarenakan sanksi pidana kumulatif yang terdapat pada Ketentuan Pidana dalam UU tersebut adalah sanksi pidana penjara dan denda. Karena korporasi senyatanya tidak dapat dikenakan pidana penjara karena tidak memiliki "badan", maka dapat dikatakan bahwa yang bertanggungjawab apabila korporasi mempunyai kesalahan dalam UU Penyandang Disabilitas ini ialah pengurus dari korporasi tersebut.

Tidak bisanya korporasi untuk dimintai pertanggungjawaban berupa pidana penjara juga sudah ditegaskan dalam Peraturan Mahkamah Agung Republik Indonesia Nomor 13 tahun 2016 tentang Tata Cara Penanganan Perkara Tindak Pidana Oleh Korporasi (selanjutnya disebut PERMA 13 tahun 2016) Pasal 25 ayat (3) yang mengatakan bahwa pidana Pokok yang dapat dijatuhkan terhadap Korporasi adalah pidana denda. Peraturan Mahkamah Agung itu sendiri dibuat agar menjadi acuan bagi para penegak hukum dalam menyelesaikan perkara dengan korporasi sebagai subjeknya. Namun, walaupun PERMA 13 Tahun 2016 telah menyatakan bahwa pidana pokok yang dapat dijatuhkan oleh Hakim kepada korporasi adalah berupa pidana denda dan/atau pidana tambahan, pada Pasal 4 Ayat 1 Peraturan Mahkamah Agung tersebut menyatakan bahwa "Korporasi dapat dimintakan pertanggungjawaban pidana sesuai dengan ketentuan pidana Korporasi dalam undang-undang yang mengatur tentang Korporasi". Pasal ini 
memberikan pengertian bahwa PERMA 13 Tahun 2016, walaupun mengatur secara khusus mengenai tata cara penanganan tindak pidana oleh korporasi dan menyatakan bahwa pidana pokok yang dapat dijatuhkan kepada korporasi hanya berupa pidana denda, tetap akan mengikuti ketentuan pidana yang ada dalam undang-undang yang berkaitan dengan korporasi sebagai subjeknya.

Tidak mungkin untuk menjatuhkan sanksi pidana kepada suatu korporasi berupa pidana penjara, sehingga sebagai konsekuensinya adalah tidak mungkin menuntut suatu korporasi sebagai pelaku tindak pidana berdasarkan suatu undangundang pidana apabila dalam undangundang tersebut ditentukan bahwa sanksi pidana yang dapat dijatuhkan kepada pelaku pidana adalah kumulasi pidana penjara dan pidana denda (keduanya sanksi pidana tersebut bersifat kumulatif, yaitu harus kedua sanksi tersebut dijatuhkan kepada pelaku tindak pidana yang bersangkutan). Dengan kata lain, korporasi hanya mungkin dituntut dan dijatuhi pidana apabila sanksi pidana penjara dan pidana denda di dalam undangundang itu ditentukan sebagai sanksi pidana yang bersifat alternatif (artinya dapat dipilih oleh hakim). Apabila kedua sanksi pidana itu bersifat alternatif, maka kepada yang bersangkutan dapat dijatuhi sanksi pidana penjara saja, atau sanksi pidana denda, atau kedua sanksi tersebut dijatuhkan secara kumulatif. Sementara kepada korporasinya hanya dijatuhkan sanksi pidana pokok berupa pidana denda karena korporasi tidak mungkin menjalani sanksi pidana penjara. Apabila sanksi pidana ditentukan secara kumulatif antara pidana penjara dan pidana denda, bukan secara alternatif, tetapi ada ketentuan lain dalam undang-undang itu yang menentukan dengan tegas bahwa dalam hal tuntutan dilakukan terhadap korporasi akan dijatuhkan sanksi pidana denda saja (mungkin dengan pidana denda yang lebih berat), maka sanksi pidana penjara dan denda yang ditentukan secara kumulatif itu tidak menghalangi dijatuhkan pidana denda saja kepada korporasi.

Perma No. 13 Tahun 2016 mengadopsi doctrine identification di mana pembebanan pertanggungjawaban pidana kepada korporasi ditentukan pada siapa yang memiliki peranan penting dalam mengendalikan korporasi, sehingga penuntut umum harus dapat mengidentifikasikan bahwa perbuatan individu tersebut dipandang sebagai perbuatan korporasi. Individu tersebut tidak hanya sebatas pada pengurus korporasi tetapi individu yang merupakan directing mind dari korporasi tersebut. Ketentuan ini sejalan dengan konsep beneficial ownership yang sudah mulai diterapkan dalam beberapa peraturan di duniainternasionaldandiIndonesiaseperti Peraturan Bank Indonesia Nomor: 11/ 28 /PBI/2009 tentang Penerapan Program Anti Pencucian Uang dan Pencegahan Pendanaan Terorisme Bagi Bank Umum. Hal ini memungkinkan untuk dapat meminta pertanggungjawaban pidana baik korporasi maupun individu yang merupakan beneficial owner dari korporasi tersebut. Lebih lanjut ketentuan ini tidak lepas dari banyaknya paper company dan vehicle company yang memang sengaja dirikan untuk melakukan tindak pidana dan sebagai tameng untuk memutus pertanggungjawaban pidana.

Dengan kata lain, dapat dikatakan bahwa perbuatan korporasi adalah perbuatan dari pengurus korporasi tersebut yang dilakukan atas nama korporasi dan itu dilakukan dengan suatu maksud atau di sengaja dan juga karena suatu kelalaian.

Mengenai kesalahan dari Korporasi, berdasarkan Pasal 4 Angka 2 Peraturan Mahkamah Agung Nomor 13 Tahun 2016 tentang Tata Cara Penanganan Perkara Tindak Pidana Oleh Korporasi, dapat ditentukan dengan 1) Apakah korporasi 
mendapatkan suatu keuntungan atau manfaat dari suatu tindak pidana, 2) Apakah tindak pidana tersebut dilakukan untuk kepentingan dari korporasi itu sendiri, 3) Korporasi mengetahui adanya suatu tindak pidana yang terjadi akan tetapi korporasi diam saja, dan 4) Korporasi tidak melakukan langkah-langkah yang diperlukan untuk melakukan pencegahan, agar mencegah terjadinya dampak yang lebih besar dan memastikan kepatuhan terhadap ketentuan hukum yang berlaku guna menghindari terjadinya tindak pidana.

Pada UU Penyandang Disabilitas tidak dicantumkan sama sekali mengenai apa yang harus di lakukan apabila tuntutan dilakukan terhadap korporasi. Walaupun pada kenyataan korporasi adalah sebagai subjek yang nyata dalam UU Penyandang Disabilitas ini. Hal ini akan membuat beban pertanggungjawaban korporasi berpindah ke pengurus korporasi.

Model pertanggungjawaban pidana Korporasi di mana korporasi sebagai pembuat dan pengurus bertanggungjawab, menegaskan bahwa korporasi adalah sebagai pembuat dari tindak pidana tersebut. Pengurus korporasi kemudian ditunjuk sebagai yang bertanggungjawab dari perbuatan yang dilakukan oleh korporasi, di mana perbuatan ini adalah apa yang dilakukan oleh alat pelengkap dari korporasi itu sendiri, yang di dasarkan pada wewenang ataupun anggaran dasar korporasi. Dengan demikian, tindak pidana yang dilakukan oleh korporasi, dapat dikatakan sebagai tindak pidana yang di lakukan oleh seseorang dari korporasi tersebut. Sifat dari perbuatan yang menjadikan tindak pidana itu adalah onpersoonlijk, yakni orang yang memimpin korporasi bertanggungjawab pidana, terlepas dari pengetahuannya tentang perbuatan tersebut. Contoh peraturan yang mengatur tentang pengurus yang bertanggungjawab terhadap perbuatan korporasi yakni pasal 19 Undang-Undang
Nomor 1 Tahun 1951 tentang berlakunya Undang-Undang Kerja Nomor 12 tahun 1948 dari RI untuk seluruh Indonesia, dan lain-lain. ${ }^{43}$

Model pertanggungjawaban pidana korporasi seperti pada UU Penyandang Disabilitas ini juga terdapat pada Undangundang Nomor 41 Tahun 1999 tentang Kehutanan, di mana pada Pasal 78 angka 14, yaitu "Tindak pidana sebagaimana dimaksud dalam Pasal 50 ayat (1), ayat (2), dan ayat (3) apabila dilakukan oleh dan atau atas nama badan hukum atau badan usaha, tuntutan dan sanksi pidananya dijatuhkan terhadap pengurusnya, baik sendiri-sendiri maupun bersamasama, dikenakan pidana sesuai dengan ancaman pidana masing-masing ditambah dengan $1 / 3$ (sepertiga) dari pidana yang dijatuhkan.". Dalam pasal tadi, dapat dilihat bahwa UU Kehutanan memberikan beban pertanggungjawaban pidana terhadap korporasi kepada pengurus dari korporasi tersebut. Pasal tersebut juga menambahkan sanksi apabila korporasi yang melakukannya.

\section{SIMPULAN}

Bentuk pertanggungjawaban pidana Korporasi dalam Undang-Undang Nomor 8 Tahun 2016 tentang Penyandang Disabilitas adalah menggunakan sifat pertanggungjawaban pidana korporasi berupa, korporasi sebagai pembuat atau pelaku tindak pidana, tapi pengurus korporasilah yang harus bertanggungjawab. Hal ini dapat terlihat dari bentuk penjatuhan pidana dalam undang-undang ini yang berupa pidana kumulatif penjara dan denda. Akan lebih baik apabila rumusan ketentuan pidana yang ada pada UU Penyandang Disabilitas memisahkan antara subjek hukum orang dan korporasi. Dan akan lebih memudahkan bagi penegak hukum

${ }^{43}$ Muladi dan Dwidja Priyatno, Pertanggungjawaban Pidana Korporasi, Kencana Prenada Media Group, Jakarta, 2010, h. 86 
apabila sanksi pidana khususnya untuk korporasi di dalam UU Penyandang Disabilitas ini mengikuti apa yang ada di Peraturan Mahkamah Agung Republik Indonesia Nomor 13 Tahun 2016 tentang Tata Cara Penanganan Tindak Pidana Oleh Korporasi, agar memudahkan penegak hukum nantinya apabila terjadi kasus tindak pidana korporasi berkaitan dengan UU Penyandang Disabilitas.

\section{DAFTAR PUSTKA}

\section{Buku dan Jurnal}

Adji, Oemar Seno, 1984, Hukum (Acara) Pidana Dalam Prospeksi, Erlangga, Jakarta.

Ahmad Zuhairi, 2015, Konstruksi Perlindungan Hukum Bagi Pengadu/Pelapor Kerugian Konsumen Dari Tuntutan Pencemaran Nama Baik Oleh Pelaku Usaha/Produsen, Jurnal IUS Kajian Hukum dan Keadilan, Vol. III, No. 7, Edisi April.

Ali Mahrus, 2013, Asas-Asas Hukum Pidana Korporasi, Edisi 1, Cet. 1, Rajawali Press, Jakarta..

Arif, Barda Nawawi, 1998, Perbandingan Hukum Pidana, PT. Raja Grafindo Persada, Jakarta.

,2001, Masalah Penegakan Hukum dan Kebijakan Penanggulangan Kejahatan, PT. Citra Aditya Bakti, Bandung.

Bahri, Fahrizal Pranata, 2013, Pertanggungjawaban Korporasi Terhadap Tindak Pidana Pemalsuan Domain Dalam Pengaturan Hukum Pidana Indonesia, (Jurnal Skripsi Universitas Mataram), Mataram.

Bawengan, Gerson W., 1983, Hukum Pidana di dalam Teori dan Praktek, Pradnya Paramita, Jakarta.
Chazawi, Adami, 2008, Pelajaran Hukum Pidana 1 (Stelsel Pidana, Tindak Pidana, TeoriTeori Pemidananaan, Dan Batas Berlakunya Hukum Pidana, Rajawali Pers, Jakarta.

Geary, Roger, 2002, Understanding Criminal Law, Cavendish Publishing Limited, Oregon.

Huda, Chairul, 2006, Dari Pidana Tanpa Kesalahan Menuju kepada Tiada Pertanggungjawaban Pidana Tanpa Kesalahan, Kencana, Jakarta.

Hutauruk, Rufinus Hotmaulana, 2013, Penanggulangan Kejahatan Korporasi Melalui Pendekatan Restoratif, Cetakan Pertama, Sinar Grafika, Jakarta Timur.

Lamintang, P.A.F, 1984. Dasar-Dasar Hukum Pidana Indonesia, Sinar Baru, Bandung..

M., Soeharto R., 1996, Hukum Pidana Materiil: Unsur-Unsur Objektif sebagai Dasar Dakwaan, Edisi Kedua, Sinar Grafika, Jakarta.

Malikoel Adil, Soetan K., 1955, Pembaharuan Hukum perdata Kita, PT .Pembangunan, Jakarta.

Muladi dan Priyatno, Dwidja, 2010, Pertanggungjawaban Pidana Korporasi, Kencana Prenada Media Group, Jakarta..

Moeljatno, 2009, Asas-Asas Hukum Pidana Cet. VII, Rieneka Cipta, Jakarta..

Naskah Akademik RUU Penyandang Disabilitas.

Saleh, Roeslan, 1981, Perbuatan Pidana Dan Pertanggungjawaban Pidana, Aksara Baru, Jakarta.

Setiyono H., 2003, Kejahatan Korporasi: Analisis Viktimologis dan Pertanggungjawaban Korporasi 
Regy Trihardianto|Pertanggungjawaban Pidana Korporasi Terhadap Hak Penyandang Disabilitas di

dalam Hukum Pidana Indonesia, Bayumedia Publishing, Malang.

Sjawie, Hasbullah F., 2013, Direksi Perseroan Terbatas serta Pertanggungjawaban Pidana Korporasi, PT. Citra Aditya Bakti, Bandung.

\section{Peraturan Perundang-undangan}

Indonesia, Undang-Undang Dasar Negara Republik Indonesia Tahun 1945

Indonesia, Undang-Undang Nomor 1 Tahun 1946 tentang Peraturan Hukum Pidana jo Undangundang Nomor 73 Tahun 1958 tentang Menyatakan berlakunya undang-undang Nomor 1 Tahun 1946 Republik Indonesia tentang Peraturan Hukum Pidana untuk seluruh wilayah Republik Indonesia dan mengubah Kitab Undang-undang Hukum Pidana (Lembaran Negara Tahun 1958 Nomor 127, Tambahan Lembaran Negara Nomor 1660);

Indonesia, Undang-Undang Nomor 4 Tahun 1997 Tentang Penyandang Cacat (Lembaran Negara Tahun 1997 Nomor 9, Tambahan Lembaran Negara Republik Indonesia Nomor 3670)

Indonesia, Undang-Undang Negara Republik Indonesia Nomor 39 Tahun 1999 Tentang Hak Asasi Manusia (Lembaran Negara Tahun 1999 Nomor 165, Tambahan Lembaran Negara Republik Indonesia Nomor 3886)

Indonesia, Undang-Undang Nomor 8 Tahun 2016 Tentang Penyandang Disabilitas (Lembaran Negara Tahun 2016 Nomor 69, Tambahan Lembaran Negara Republik Indonesia Nomor 5871)

Peraturan Mahkamah Agung Republik Indonesia Nomor 13 tahun 2016 tentang Tata Cara Penanganan Perkara Tindak Pidana Oleh Korporasi 